\title{
Portraits of Antun Gustav Matoš by Josip Vaništa and Antun Babić
}

\begin{abstract}
KusikVlastimir,Portraits of Antun Gustav Matoš by Josip VaništaandAntun Babić. „Poznańskie Studia Slawistyczne” 7. Poznań 2014. Publishing House Science and Innovate. pp. 275-284. ISBN 978-83-63795-79-5. ISSN 2084-3011.

This essay deals with two visual art portraits by the painter Josip Vaništa and the sculptor Antun Babić. The subject is Antun Gustav Matoš, whom each artist depicts according to his own artistic vocabulary and visual language. There is a difference in both the form and the motivation. For Josip Vaništa, A.G. Matoš announced the dawn of Croatian modernism, which was his painterly point of departure, while for A. Babić, A.G. Matoš was a literary figure who belonged to s specific physical space.
\end{abstract}

Keywords: portrait; figure; scene; modernism; neo-traditionalism; new avant-garde

Cultural singularity and versatility of Antun Gustav Matoš's output still today, as it did during his lifetime, attracts attention and results in ever-new interests, discoveries and interpretations. The reason for this is the breadth of his interests, addressed by literary theory and criticism and in writings on literary history. His prose, poetry, literary and art critiques, polemics, and pamphlets as well as his other public activities are viewed as works of an intellectual activist of a wide spectrum of interests and, above all, a poignant expression.

In the realm of visual arts, there is an obvious respect of the highest order for Matoš. His art critiques are especially valuable for the history of art, but in practical terms, his influence and importance in the promotion and affirmation of modernism and modernity, for which he paved the way and opened new vistas, cannot be forgotten. 
Art criticism of Croatian modernism, which directly preceded expressionism and which also paradigmatically announced, for our art, revolutionary events, achieved its apex through texts by Antun Gustav Matoš, the brilliant poet, writer of essays, short stories, travelogues, periodical pieces, and critiques, the polemicist, culture and art chronicler, boycotted journalist, bohemian and constant traveller from Zagreb to Belgrade to Munich to Paris to Vienna. His personality marked this era. Even more so, Matoš's work, with its ,,complex contradiction” represented the realization of the aspirations of Croatian modernist movement (Galjer 2000: 89).

However, not only art critics appreciated Matoš's role and importance in promoting the idea of modernism in his brilliant texts aimed at broadening the understanding of visual art, primarily focusing on paintings by Miroslav Kraljević and sculptures by Ivan Meštrović and Robert Frangeš Mihanović. His output as well as his likeness was and still is also a significant source of inspiration for both his contemporaries and current painters and sculptors, who have always expressed their positions on and opinions about Matoš. Sculptors in particular have contributed to this end, as in the case of monuments and busts by Ivan Kozarić and Marija Galetović Ujević, respectively. These two types of sculptural work are examples of the ways literary figures are represented in visual art in specific interpretations through individual visual vocabularies of the artists. This is an important observation because monuments and paintings are often victims of the commissioning requirement dictates as well as romantically ,inspired" improvisations of questionable artistic value. Bearing in mind such instances, art criticism has always found portraits of writers, in the mediums of paintings and sculptures, an attractive topic since art criticism tries to make sure that visual vocabulary is properly articulated in the interpretation of the subject. One recent exhibition clearly showed to what extent such interpretation can achieve the goal, namely a portrait of a writer.

Not by chance and not without reason, the central and most valuable portrait at this exhibition is by the painter who is the focus of this text, Josip Vaništa. This is the portrait of a writer in which the painter marks and displays his own artistic expression. The importance of this portrait is not only expressed through written text; an enlarged detail of the work is also depicted on the front cover of the catalogue. 
As a reminder, I have to mention that a portrait in visual arts is executed in three ways; a portrait face-to-face, i.e. the subject poses for the artist, a portrait from memory, and a portrait made from a secondary source, such as a photograph or other images. For this work I have chosen two important representatives of Croatian art, the painter Josip Vaništa and the sculptor Antun Babić. It is clear that these two artists executed their portraits from a photograph. This is important for their approach because it provided them with certain freedom, which in turn allowed them to display the breadth of their visual vocabulary. This is not only the matter of each artists's elaborate stylistic and formative morphology but also a way to understand the motive of their choice and the answer to the question, „Why Antun Gustav Matoš?". This text attempts to explain that the method answers the question why they were created. From the point of view of the motives and different approaches to them, we find another difference in visual languages of these artists and the answer to the question why Matoš was depicted with that particular method.

The painter Josip Vaništa, born in Karlovac in 1924, is an unquestionable artistic treasure of contemporary Croatian art. In his very beginnings, Vaništa marked his painting with fine sensibility and a sense of tradition, following in the footsteps of painters Josip Račić and Milan Steiner, i.e. the second generation of Croatian modernists. As time went by, Vaništa distanced himself from the figurative and moved towards the abstract, engaged in art informel for a short time, only to conclude with radical minimalism, as exemplified in: A Black Line on a Silver Background (1964) and A Gray Painting on a White Background (1965). This trend in his work found support in the artistic circle which he founded, called Gorgone. However, later, in the early eighties, Vinita moved away and still today keeps the distance from the radical neo-avant-garde, whose spiritual originator he was, and toward contemplative intimism that respects painterly traditions, which inspire him. He identifies himself as a painter of neo-avant-garde as well as neo-traditionalism. This was the reason why his art at the mentioned exhibition was represented by two pieces: a drawing of Miroslav Krleža (1973) and A Black Line on a Silver Background (1964). In this way, the duality of his artistic nature is emphasized and signified.

The drawing and the painting, each in its own way, leads us toward the portrait of A.G. Matoš. The drawn portrait of Miroslav Krleža is one in 


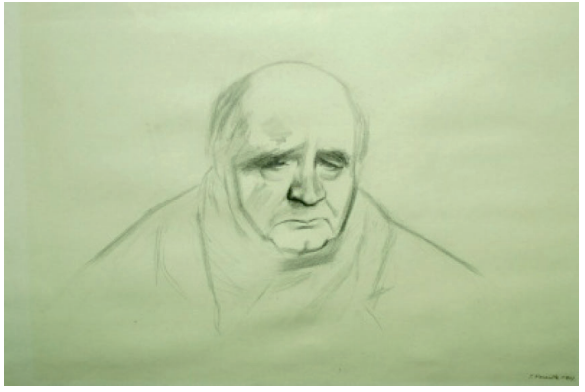

Josip Vaništa, The Portrait of Krleža, 1973, pencil, paper, $31 \times 42$, Gallery of Fine Arts, Osijek, G-1038

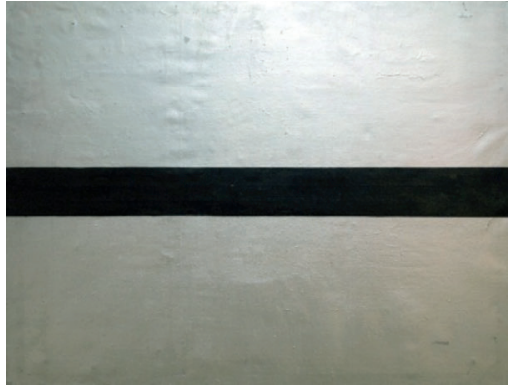

Josip Vaništa, A Black Line on a Silver Background, 1964, oil painting on canvas, $140 \times 180$, Gallery of Fine Arts, Osijek, S-1018

the series of Vanessa's self-portraits and portraits (Josip Račić, Janko Polić Kamov, Ljubo Babić) created at other times. Two pencil drawing methods are at work here: a fine, misty line interrupted up to create smaller lines and an uninterrupted line drawn as the hand synchronizes with the eye while the artist looks at the subject. Vinita explains the acceptance of this method as the result of his fascination with Croatian modernism, primarily that of Josip Račić and Milan Steiner, whose paintings and drawings he pored over so much that their lines became his own, which in his own work eventually merge into one black line without a beginning or an end, and whose only distinguishing element in different pieces is the background. However, Vaništa was impressed not only by the painters of Croatian modernism. He was equally fascinated by the literary figures of Croatian modernism, and, among others, A.G. Matoš.

An exhibition in the Gallery of Art in Osijek in 1985 showcased Vaništa and other members of Gorgone. Vaništa's transition and return from the neo-avant-garde to neo-traditionalism, i.e., his new approach to modernism, was addressed in the foreword to the catalogue. The experience of drawing, to which Vaništa gave his own, completely new meaning is explained as follows:

The drawings in question are not just an intimate dialogue; they at the same time the artist's dialogue with kindred spirits, a sort of ,personal memory” brought into the daylight at this time, in which, to paraphrase the topic of the last Venice Biannual, 
,art looks at itself in the mirror of its own past". It is impossible to think of Vaništa from the Gorgone phase without bringing to mind examples such as Manzoni or Malevich, and to think of Vaništa's drawings from the post-Gorgone phase is impossible without recalling some names (and destinies) from our own domestic tradition. Let's mention only Račić and Steiner among the painters or Matoš, Polić Kamov and Ujević among the writers. Those who remember the paintings and poems of those forefathers and those who have heard their life stories cannot but be excited about Vaništa's conversations with himself, in which feelings and moods from the shadows of some distant past return, and which have become a strong sign of the atmosphere in the cultural environment to which this artist belongs, and which is at the same time typical of him as an individual who cannot share his role as a loner with anyone (Denegri, Kusik 1985: 28).

Intracommunication has always been a crucial trait of Vaništa's artistic being, just as a retrospective of an artist's life is a certain pinnacle and restatement of that dialogue. This was the case at a recent retrospective of Josip Vaništa, the title of which already marks the attitude of the author toward the exhibition, namely, that it needs to be cancelled since every such

A.G. Matoš, 2013, reproduktion of the drawing from the 80 's, $68,5 \times 48,5$; private collection, Zagreb

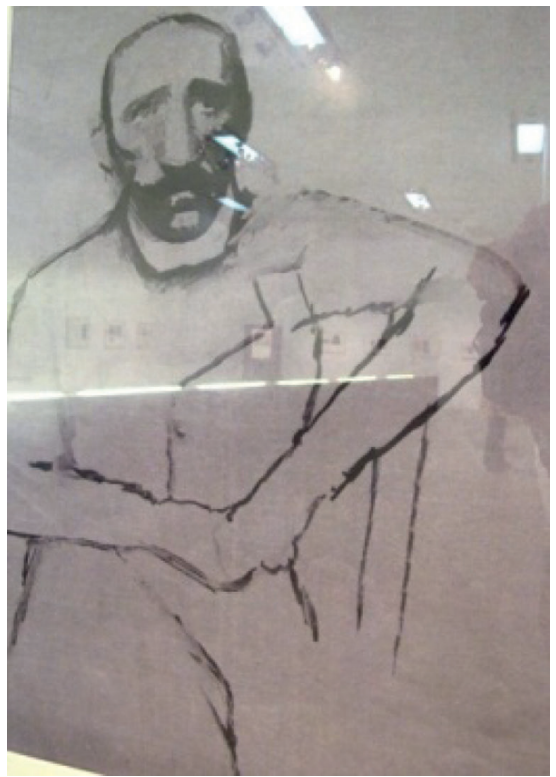


exhibition is new and different. However, we are tracing the origins of Vaništa's portrait of Matoš, of which I had been aware but had not seen either as a reproduction or in monographs. In the retrospective, the biggest and most encompassing so far, exhibit \# 108 is identified as follows:

This description alongside the painting was very unusual for an exhibit but very accurate and precise about the content. Its print, photographed under glass but not included in the catalogue, presented in this way has a definite mystifying dimension. This indeed is a drawing, but only the print is exhibited, which is a typical Gorgonesque gesture; moreover, it is a Vaništa gesture also because it ties the Gorgonesque and the post-Gorgonesque. A Gorgon approach is to exhibit a print of a drawing, but the nature of the drawing is post-Gorgone. In this drawing lines fuzzy at their beginnings condense on their way to becoming one line without the beginning or an end. However, it also includes inversion. This drawing came into existence the black line phase; it is its transformation. Therein lies the singularity of this work. Matoš's likeness is a particular motivation and inspiration for this painter. It is unnecessary to say that in Vaništa's work, such gestures, moves, settings and presentations are never a coincidence.

The sculptor Antun Babić, born in Bijeljina in 1931, is a big name in Croatian art and unquestionably the most important living art institution in these parts. When one says ,these parts”, with Vinkovci as its centre, one means a very specific cartographic designation of a very specific cultural standing, importance and content. It is important to say that A. Babic developed the contemporary nature of his artistic poetics in this particular location. Namely, he is not an artist like Vaništa, whose native land is also his artistic native realm, modernism or avant-garde. He is exactly the opposite and so is his portrait of A.G. Matoš, not only in form but also in content, i.e. the motive and reason for the creative process.

One needs to clarify what space one is talking about when emphasizing that the painter and sculptor, just from that space, evokes the likeness of the writer A.G. Matoš. Another artist from Vinkovci writes about that space as follows:

This is the Slavonian Biannual; however, but I intentionally do not want to talk only about Slavonia, but rather about Pannonia, Northern Croatia, Croatian Plains, the interfluvium between the Drava and the Sava, in general the space Slavonia belongs to, since the term „Pannonian Croatia” is more encompassing. The term „Slavonia” 
is narrower, more regional, although under „Slavonia” we should understand the whole Pannonian Croatia, whose today's narrower, smaller, province of Slavonia is its core and symbol (Tomičić1968: 5).

Antun Babić expresses his art from this space as a sculptor and painter and especially as a graphic artist. Of course, Babić's morphology is compact and consistent, as has been thoroughly elaborated in numerous texts and monographs.

Still, Babic is somewhat more outstanding as a graphic artist than as a sculptor or painter. Namely, graphic sheets and portfolios as whole seem to have offered this artist the broadest possibilities for expression, which is not only visual but also literary. Not only because Babić's visual output is accompanied with words and sometimes whole stories but also because all sheets or images in a portfolio have messages that can be read on several levels. This
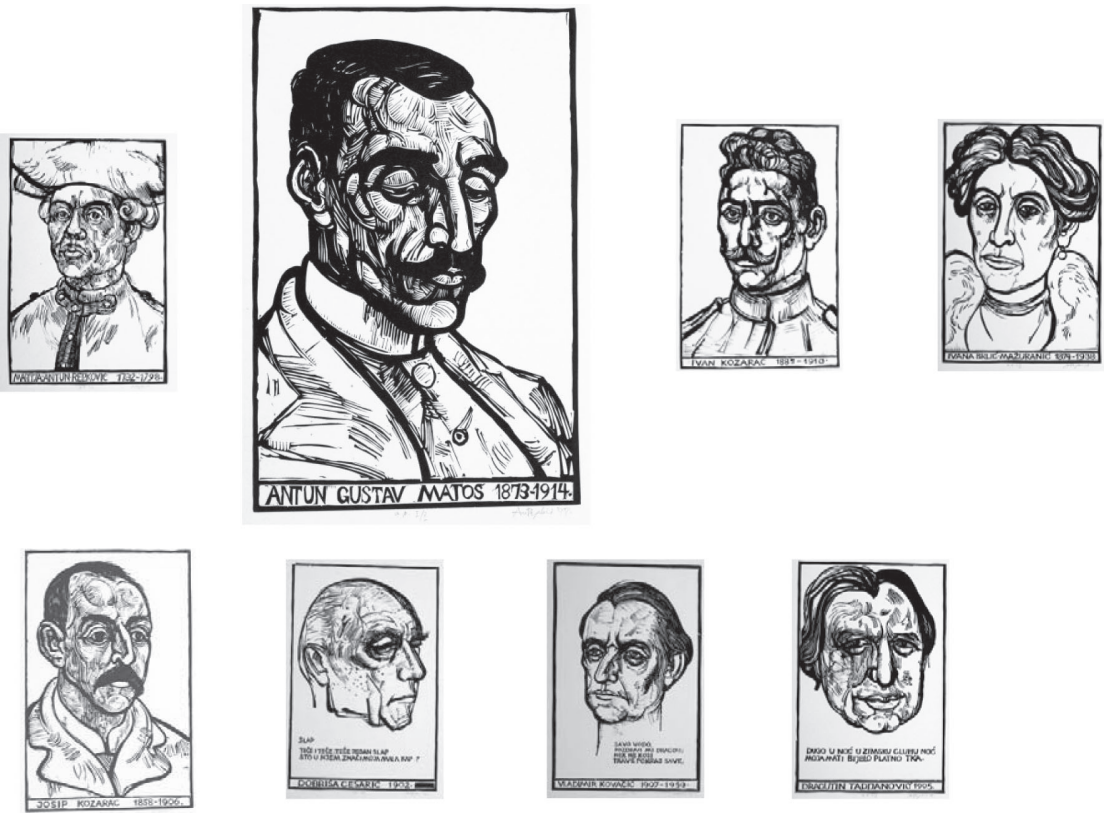

Antun Babić, Writers, linoleum print, Gallery of Fine Arts, Vinkovci 
poetic content, reminiscent of Borg's stories, are present in two of Babić's portfolios, People on the Stage (1977) and The Fall of the City of Taj (1982). However, his third graphic portfolio, Writers (1978), is of a different artistic nature; the poetic content is only a part of it. The most important part is the range of writers. Included in this selection are Matija Antun Reljkovic (1732-1798), Josip Kozarac (1858-1906), Antun Gustav Matoš (1873-1914), Ivan Kozarac (1885-1910), Ivana Brlić Mažuranić (1874-1938), Vladimir Kovačić (1907-1959), Dobriša Cesarić (1902) and Dragutin Tadijanović (1905). This selection clearly reveals its content. These are writers born in this space whose content we recognized in the words of the poet Zlatko Tomičić. These are Croatian writers, and the first among them is, and of present interest, A.G. Matoš.

The graphic artist A. Babić, following his artistic sculptural and painterly interests and built in his portfolios literary motivations; in this portfolio he expresses both verbally and visually his views as to who holds this space as his/her home ground. He supports his choice with visual vocabulary that does not make a concession to the content, in this case superfluous description of the background of the portrayed subject. Such is, of course, the portrait of A.G. Matoš. The firm, compact contours of the subject's physiognomy express both themselves and the figure they represent. Babic is at home in this stylistic and formal mode, and the portrait of A.G. Matoš attests to that.

We have presented the image of A.G. Matoš both physically and as an artistic vision by two important Croatian artists. Although they approached the subject from different standpoints and represented the image in differing forms, the phenomenological importance of these interpretations, however much artistically valuable, first and foremost belong to the observed subject. The artists have maybe discovered an unknown or invisible dimension of the subject, which, to say the least, is beneficial for understanding of the totality of Matoš's cultural singularity mentioned at the beginning of this study.

\section{Literature}

Denegri J., Kusik V., 1985, Marijan Jevšovar, Julije Knifer, Ivan Kožarić, Đuro Seder, Josip Vaništa, Osijek.

Galjer J., 2000, Likovna kritika u Hrvatskoj, 1868-1951, Zagreb. 
Susovski M., 1988, Josip Vaništa. Crteži 1953-1988, Zagreb.

Tomičić Z., 1968, Tonska simfonija Slavonije, Bienale Slavonaca 1967, Vinkovci-Osijek.

Vaništa J., 2013, Ukidanje retrospektive = Abolition of retrospective, ed. N. Beroš, transl. I. Polak, A. Jelčić, G. McMaster, Zagreb. 
